\title{
Impact of Covid-19 on University Final Year Internship Students
}

\author{
Asif Zaman, Hasanul Banna, Mohammad Arshadul Alam Rakib, Shakil Ahmed, \\ Mohammad Monirujjaman Khan
}

Department of Electrical and Computer Engineering, North South University, Dhaka, Bangladesh

Email: monirujjaman.khan@northsouth.edu, arshadul.rakib@northsouth.edu, shakil.ahmed10@northsouth.edu, hasanul.banna@northsouth.edu, asif.zaman@northsouth.edu

How to cite this paper: Zaman, A., Banna, H., Rakib, M.A.A., Ahmed, S. and Khan, M.M. (2021) Impact of Covid-19 on University Final Year Internship Students. Journal of Software Engineering and Applications, 14, 363-388.

https://doi.org/10.4236/jsea.2021.148022

Received: June 21, 2021

Accepted: August 16, 2021

Published: August 19, 2021

Copyright $\odot 2021$ by author(s) and Scientific Research Publishing Inc. This work is licensed under the Creative Commons Attribution International License (CC BY 4.0).

http://creativecommons.org/licenses/by/4.0/

\begin{abstract}
Covid-19 has significantly changed the lives of millions of people worldwide, especially university students. The pandemic has a strong influence on university students, all of whom are concerned about their future. This paper addresses the issue of the impact of the pandemic on final-year internship students. The work's goal is to illustrate how Covid-19 outbreaks in the last year have influenced final-year internship university students and their internships, internship opportunities, career prospects, psychological well-being, and motivation. The Covid-19 impact is so huge on education. The purpose of this study is to show how it hampers a specific sector, like university final year internship students. In the future, if anybody wants to know the situation of intern students at universities, they will get to know it. The work aims to examine and classify the fundamental problems that final year students have faced in finding an internship during the Covid-19 pandemic period, the obstacles they face in finding an internship, how universities help their students, how students get internships, why internship opportunities are getting limited, and how students overcome obstacles in finding an internship. To complete this research, first, we chose around 25 questions and worked on them to survey different university students in Bangladesh. The research was performed using reviews of different research papers and a survey approach. The survey has been developed using the Google Forms platform. Three hundred students who are currently studying at public and private universities in Bangladesh participated in the study. Students have been asked to answer 25 questions online. The data was evaluated concretely. Most of those students were from the last semester or last year of their university life. And in the end, we finally came to a conclusion about how the research worked. It creates a scenario where over 300 students have shared their thoughts on each aspect of the research questions. Whether they suffer or not, most of them
\end{abstract}


find it pretty difficult to complete their internship because most of the participants were university final year students, and after completing all the research, the results can be written as if there was no situation like this, it would be much easier and more convenient for all the final year university interns.

\section{Keywords}

Covid-19, University Students, Impact, Internship, Review, Survey

\section{Introduction}

Covid-19 was caused by the severe acute respiratory syndrome coronavirus (SARS-CoV-2). The Covid-19 [1] pandemic has spread worldwide since the outbreak in Wuhan (China) in December 2019. Covid-19, which was first erupted in China in December 2019, and after that, it serenaded all over the world. For this reason, all institutions, including universities, have also been closed all over the world. Following this situation, the Bangladesh government also decided to close all educational instructions. However, when the Covid-19 situation was not in control, the government decided to take educational institutions' classes online. But, final year university students could not complete their internship online because an internship means students have to be physically present in an institution to gather experience.

Final year internship students suffered a lot for the Covid-19. Most of the institutions were closed because of Covid-19. So, the internship is not offered, but without an internship, a student can not finish his/her graduation also; after reopened institutions, most of the institutions did not offer internships for safety issues. Nevertheless, students managed to overcome these obstacles.

Most of the literature is on the impact of Covid-19 on the education sector. A few pieces of literature were found which discuss the impact of Covid-19 on final year internship students.

In [1], author Bussma Ahmed discusses the Impact of the Covid-19 Pandemic on Internship Activities at Health Organizations in Saudi Arabia [1], where he discusses the impact of Covid-19 on internship activities in health organizations in Saudi Arabia. The study is a secondary analysis of the data set collected from 101 health science interns from different health organizations. The majority of interns was trained or started their internships at public health organizations (64.29\%), while $6.12 \%$ and $29.59 \%$ were at private and other health organizations, respectively. During the Covid-19 pandemic, most health organizations chose to continue the internships $(76.53 \%)$, while others $(23.47 \%)$ decided to suspend training. Health organizations have taken different actions to overcome internship issues during the Covid-19 pandemic [1].

In [2], the author writes about the Internship Program Assessment, where he writes the impacts of Covid-19 have been significant, which causes organizations to consider whether their internship programs [2]. Continuance would be feasi- 
ble in 2020 or beyond, in light of the challenges that Covid-19 presents to hosting these programs. In our client discussions, $44 \%$ of participants shared that they kept their internship program but have found it necessary to modify it in some way. Given current world conditions, organizations globally have had to weigh whether to cancel their programs or modify them and, if so, to what extent [2].

In [3] the author writes about the "Impact of Covid-19 Pandemic on Training", where he writes, we intend to provide the full training experience of our internship during the 2021-22 academic year [3]. However, there will be necessary modifications to the program to minimize risks to patients, employees, trainees, and the general public resulting from the Covid-19 pandemic. Our website's Internship Homepage includes a Covid-19 banner and links to how we strive to provide care and information during the pandemic at The University of Kansas Medical Center. We are currently providing remote access to care, supervision, and didactic activities when it is not necessary or appropriate to have in-person contact. Many aspects of training, particularly in integrated care settings and inpatient sites, require in-person involvement to be meaningful for the experiences. In those instances, we strive to reduce the risks involved by carefully considering safety measures identified by the medical center, department, division, and internship program. Many of these are evident in the links on our homepage. Our academic medical center's leadership is well-positioned through its expertise and multidisciplinary representation to offer the best safety standards for all involved in learning and receiving care here. We receive daily briefings from a multidisciplinary team at the medical center regarding Covid-19. This includes much general information but also often items about self-care during the pandemic. We want to keep you and others safe while providing you with the best training experience possible! We welcome your input or concerns at any time [3].

The Coronavirus pandemic is a worldwide emergency. Various countries have decided to close schools, colleges, and universities. Coronavirus has disturbed training frameworks around the planet, pushing most youngsters briefly out of school. With many understudies taking a crack at schools, universities, and colleges, Bangladesh is among the nations generally influenced by total closure. With all foundations shut for right around one year. Be that as it may, the misfortune in schooling hours is not the lone effect approaching from the Covid-19 emergency [4]. On top of learning, instructive organizations are an essential wellspring of social security, nourishment, and well-being, just as psychosocial supports all the understudies.

The Covid-19 pandemic might seriously influence the vocations of the current year's college assistant understudies [5]. They have experienced critical indicating breaks in the last piece of their assessments. They are experiencing big breaks in their assessments. In conclusion, they are likely going to graduate at the beginning of an overall extended slump. Proof recommends that helpless economic situations at work market passage cause laborers' to acknowledge lower-paid po- 
sitions and effectively affect a few vocations. This would cause a gigantic hole in the premise of income between others.

Some have had their temporary positions deferred, as opposed to dropping. In any case, these numbers are minimal. They are only a stage away from finishing; however, far-fetched, the pandemic causes them.

Additionally, during this pandemic circumstance, in numerous cases, scholarly projects that require entry-level positions are thinking of elective ventures or encounters or projects that can fulfill the basic guidelines of a temporary job. This could imply that home or office, this kind of exploration projects supervised by workforce or counsel, and comparative sorts of learning encounters that are intently attached to the understudy's academic program. In [6] authors have presented a review based research study on the online education system in Bangladesh during the Covid-19 pandemic. The same authors presented a review based study on the topic of the use of telemedicine in Bangladesh during the Covid-19 pandemic [7]. In [8] authors resented a review based on work on digital learning among postgraduate students in the time of Covid-19: A literature review. The authors of [9] presented a research study on class insight: a student monitoring system with real-time updates using face detection and eye-tracking. The development and analysis of a machine learning based software for assisting online classes during Covid-19 is presented in [10]. In [11], a review of the psychological impact on students' online learning during Covid-19 in Malaysia is shown.

All of the former research is review-based and research based, but only review-based research can identify the accurate situation of students who face getting internships during this Covid-19 pandemic. For this reason, we include a survey to get final year students' opinions about the internship. This paper presents the impact of Covid-19 for final year university-level intern students. This is a survey based approach. Some problems we want to solve in this paper are:

- How do students overcome obstacles to getting internships?

- Universities can help students to get internships.

- Remote internship can be a suitable option for the pandemic situation.

\section{Method and Methodology}

This section discusses the methods, which are used to make our paper. We use mainly quantitative survey techniques. To understand the effects of Covid-19 on final year internship students, we conducted a survey using online survey techniques for the research work. We created a Google form and added 25 questionnaires in the form. The responses were collected by giving the link of the survey form to students of almost all the public and private universities in Bangladesh. The survey results against these questionnaires are discussed in section 3.

We got almost 300 responses from the survey. We considered these samples for the research study. The questionnaires in the Google form were given in such 
a way that it covers all the information for the effects of Covid-19 on the final year internship students.

We invited the students of different universities to participate and give responses to this survey by sending them the link of the Google form via social platforms like Facebook, WhatsApp, and LinkedIn. We also post in our respective Google classroom for getting our classmates' responses.

We also used a qualitative survey technique where we physically interviewed some final year students to find out what obstacles they faced in getting an internship during the Covid-19 pandemic. We reviewed some research papers too for gathering knowledge, but there is very few search paper on this topic.

\subsection{Internships Are Vital for Learning and Developing Skills}

Learning is one thing, but putting those abilities to use in the workplace and applying them effectively is a wonderful way to explore various career routes that suit individual interests [4]. However, internships are a great way to apply cognition in the real world [4]. In the classroom, students learn, gather knowledge, and finally improve their skills, but it is different in the real world. Every student must cope with the working environment and show their skills. Therefore, experience is a must.

Having an internship gives students the courage to be familiar with the office environment and increases their marketability. Having an internship benefits students in the working environment; one in sixteen can secure a job by connecting with people, so networking is critical [4]. So, an internship is a must for the students. Having internships, students meet many people, both professionals and non-professional, in their careers.

According to the LinkedIn annual report, almost $63 \%$ of people rated soft skills as more important than technical skills [4]. So, there arises a question: what skills are? Skill is a thing such as communication, networking and connection, leadership, and teamwork beyond that experience. Having internships helps the students learn about relations such as employee relations, brainstorming the problem, structure of the leadership, etc.

All we know is that, due to the corona effect, most academic institutions have been prevented nowadays. Students do not go anywhere nowadays and use online platforms to continue their classes. It is okay for regular students; basically, students are in the 1st or 2nd year of their university life. Nevertheless, the students who are already in their 4th year or the last semester of their university life make a problem. Most students aim that they will do a job in their working life as university students. However, though the educational and working sectors are different, gathering experience is a must.

Due to the corona effect, most of the offices, institution, and job vacancies have been patronized for a long time. All of the services and job requirements have been stopped basically for this. Most offices would not offer any job/internship circular for any post. So, it is a matter of sorrow that all of the job vacancies with the paid/non-paid internship have been stopped. Furthermore, 
for this, students cannot get the opportunity to hook up with any company, and for this, they are choosing research-based papers instead of taking the internship [12].

\subsection{Internship during the Covid-19 Pandemic}

Level there are 43 public universities and 103 private universities in total in Bangladesh. Due to the Covid-19 issue, most universities run their semester/education process via an online platform. Running the online platform's semester/classes is a controversial issue nowadays. One side sees online classes as a blessing, and the other side sees them as a curse. The recent internet statistics show that it takes almost 300MB to complete 1.30-hour classes for each online class. Moreover, though most of the students are in the village or family crisis due to the financial support for the Covid-19, it becomes more difficult for them.

Though most universities continue their online classes via the online platform, most do not agree with the internship. They consider it harmful because we know in an internship, each of the students' needs almost three months to complete the process. He has to mix with many people, go for business communication and meetings, and do much outside work, so the university considers it harmful. They will not want to take any risk with their students.

Most universities did not offer internships for almost one year. The university authorities encourage "research-based paper" instead of doing the internship. Some universities offer an internship, but online, not offline, where students face the same difficulties online. They have to attend online meetings, video conferences and sometimes maintain social media relationships. However, it is online-based; sometimes, that has so happened that he cannot fully involve the clients. They cannot gather knowledge and build relationships with different people sometimes.

Some universities have changed their policies in this term. They ignore the internship and open multiple segments that they think might cover the internship's lack and cover the items they did not gather offline. Like online-based surveys, projects, research-based papers, review papers, and other categories. From the very recent lookup, students enjoy this type of research because it is very time-consuming, and they need enough knowledge to complete it. Moreover, the university also shows interest in these new types of sections and is more elastic.

\subsection{Internship during the Covid-19 Pandemic}

Due to the Covid-19 pandemic, most educational institutions have been shut down for a long time. Most of the country's institutions continue their classes via various online platforms. However, the problem begins in the final year students. Many students cannot sit for the final year examination or do an internship. At the very first of the pandemic, both students and teachers waited for some time for the thing that the pandemic would be stopped soon. However, the 
matter of sorrow will not be stopped and will become more dangerous than the previous. The thing is that the university takes an alternative decision for the final year student, and they have completed their graduation by doing an alternate option instead of doing an internship.

However, the number is very small. We did a survey that says that almost $35 \%$ - $45 \%$ of students have some alternative plan for final year students' graduation. However, the rest of the university has no plan for its students. The rest of them are waiting for the Gov't announcement and the UGC guidelines at all. However, the other university plans to keep in mind the current situation and make it flexible for the students. Because in our country, most students want to do Gov't jobs/BCS in the future. It would be a significant loss for them if they failed to complete their graduation in time because the time is age time is limited for the Gov't job.

The recent report says that a "research-based paper" or "review paper" for a particular topic/article can be an alternative way instead of doing an internship. Though there is some controversy overall, its educational performance is remarkable. Here, the students are working with a team, and each group member has to work hard to complete the part of him/herself. They have to research, read online articles, books, do a survey, need public opinion, and complete the task. Though it is time-consuming work, it is beneficial for the students to help a lot, we think.

Some of the students are doing project work instead of doing an internship. They are building it by IoT-based, AI, machine learning, web, and Android. It is also a time-consuming thing to work for at the most diminutive three months to complete the project. Here also, the project is divided by the group members, and each of the members has to complete the work within the given time. It is also a fair process rather than an internship. Here they are connected with online resources, online courses, read many articles on the particular subject, gather a piece of knowledge for the upcoming project, modify the code as the instructor wants, and generate the function and maintain it by their system.

\subsection{Obstacles Are Faced When Applying for an Internship}

When you talk about the internship, you think about something new in your study life. This is something that creates a buzz in this part of your life. You think of getting engaged with new people from different mindsets and different thoughts. But this year is not the same as in other years.

Every year any student of the internship comes to a point when he/she chooses or applies to any institution or offered by their university for their internship, but this time most of them have not got any of those. Even at this time, they can not apply to any institution for lack of opportunities. This year when any student thinks of completing their intern, they end up with thoughts like whether any institution is going to accept them or not, will there be enough safety from Covid-19 or not, will my family let me apply with all these issues, or not? These 
all create a lot of confusion among them. As a result, it has been very difficult for them to continue with so many problems.

\subsection{Internships Are Rejected for the Covid-19 Issue}

Covid-19 has impacted every sector of our lives. It's been creating problems not only in education but also in all our professional lives. If you say about the internship, it is so easy and simple that whenever one student is about to complete an internship, they must go to any company, but due to this Covid situation where all the companies are facing both financially and other problems, it becomes very tough for both the company and the students to go to the company by itself and do things like before. As a result, students are facing some serious problems.

\subsection{Usefulness of Internship in Professional Life}

In one's university life, one comes to a point when a student has to perform as an intern. This could be like one going to any company and doing usual work and others doing research on any particular topic. When students visit a company, they face new experiences, they meet new people and gain a lot of experience. They got some visuals of how they need to perform in their upcoming professional life. On the other hand, when a student decides to do any research, they choose a topic and create visuals and create a whole new thought of what they think of that topic.

\subsection{Reasons behind Different Companies' Rejection for Internship}

Every year, some companies have been very popular among internship students. Those companies were very helpful and co-operative to them also. But his year is not the same. In our modern era, we face for the first time this kind of situation where you cannot even contact others and may risk your life. At this moment, everybody, when thinking of their internship students, faces several problems. One is that companies don't show interest, and the other is safety issues. Companies do even have some obligations too.

\subsection{Universities Help to Get an Internship}

The template is used to format your paper and style the text. When the Covid-19 pandemic started, all the institutions, including educational institutions, started to close their activities by the influence of the government. Almost all the activities of the university remained off for almost two months, but the danger of Covid-19 raised day by day significantly. Then the government and UGC decided to start university classes with the help of the internet and decided to conduct classes online, but first, only private universities were able to start classes online. At the beginning of classes, teachers and students both faced difficulties because it was a new technique for everyone, but after a while, everyone was comfortable enough with the online education system. 
But then the most difficult moments came for the final year or final semester students. They had to complete an internship to complete their graduation. Without graduation, almost no one could get a job and get an opportunity for higher study because these need a graduation certificate. Another thing was for government jobs age is limited in our country. But during the start of pandemic time, almost all offices were closed for a significant time. So, most offices could not offer internships.

After the end of the lockdown, very few offices/firms offered internships. Also, there was a problem that almost all of the government universities did not conduct classes for a long period. So, it would be very difficult for students to get internships for their graduation. Some universities, which were most private universities, collected information from different companies who were searching for intern students and emailed the contact information of companies to students to help them get an internship, but most universities didn't do it.

\subsection{Remote Internship}

Before the Covid-19 pandemic, most students knew that the meaning of an internship was to attend physically in an office and work to gather experience, but the Covid-19 situation introduced us to a new thing which is remote internship/office. Basically, in remote internships, anyone can work while staying home. By using some software like zoom, Google meets one person, hosts a virtual meeting, and others can join the same meeting using a code which is provided. It is almost free, but if you want some additional features, you have to spend some money. Anyone can share his/her screen for a presentation slide; everyone can see each other. So, remote offices and internships are now a popular choice for internship students.

The remote internship also creates opportunities for the students to intern in different foreign companies while staying home. Many students started to apply to different foreign companies by collecting information through Google, and many of them were accepted. One of the sites is "internshala.com", which is an India-based website where a lot of Bangladeshi students got their remote internship and also got which was not possible before the Covid-19 pandemic.

\subsection{Preference of Students for Taking Remote Internship}

The remote internship is a new idea for most of us, which is getting popular in this pandemic situation. An internship is mainly offered to introduce students to real-life office scenarios. Students spend four years before their graduation where they learn knowledge and internship are the opportunities for students to apply theoretical knowledge to practical life which they gathered in the last four years.

Students can learn how to work in a group, how to cooperate with groupmates, how to solve problems in a group, how to communicate with colleges, how to handle corporate life, because corporate life is critical because everyone 
wants individual success here, everyone wants to use you for his/her success. So, during the internship time, a student can acquire these real-life experiences, which will help him/her in future job life. Suppose students from the computer science department accrue programming knowledge and can also do some small projects individually, but in the real world, every project is so big that many people work together on a single project. An internship helps a student to learn how to work in a team properly.

After the Covid-19 pandemic, a lot of companies stopped offering internships. Some companies then offered remote internships where students could work while staying at home. Many students also got remote internships, but they also faced some difficulties, like they could not feel the real scenario of corporate life, they could not feel the environment of the office. They worked from home, so they would have to face difficulties when they got a job because of the lack of an on-office internship.

\subsection{Problems of Remote Internship}

The level internship is for gathering real-life experience of working in the office, gathering knowledge about how to survive in corporate life, gathering knowledge about how to solve real-life problems, and gathering experience of working in a team. Internships teach you how to work in a team, how to communicate with them properly, and how to manage a bad situation [13]. But in remote internships, we may not find some real-life experience, which is important for job life.

\subsection{Virtual Team}

Virtual teams are a new idea for most of us because they got popular during the Covid-19 pandemic situation. In-office employees work as a team. Some teams contain more people, some contain less. A virtual team is the same, but here team makes virtually where team meetings are conducted virtually through software like zoom or Google Meet, where team members discuss their progress, goals, etc.

Students take internships for real-life experience, but in virtual teams' students can be faced with a real feeling of teamwork. This is because an internship student works for 3 - 4 months in a company, but if the student spends his/her full 3 - 4 months, he may not gain the real experience of how to work in a team.

\subsection{Relation of Internship in Professional Working Life}

Level Internship and research are now the two most important pillars of a person's educational and professional life. Both are important as research carries an interest in solving problems through finding solutions by researching those issues. While internships focus on living and real-life experiences and exposures.

Research is a systematic and effective analysis using an empirical approach to a particular topic, issue or problem. This is often solved by making the queries 
into a questionnaire to address the issue. Research involves a lot of analytical thinking. To research something, one needs to focus on the topic and learn about the topic/issues more precisely and attentively to come up with solutions. For a professional working life, both of them carry significant roles.

\subsection{Concern for a Future Career}

Covid-19 drastically affected our lives throughout recent years. Many countries, people, and many families have been affected very negatively by this. It changed the lives of many people. It also hampers the working lives of many people. People are now trying to cope with the term "new normal" because of this pandemic situation. Many people have lost their lives, jobs, and loved ones. It affected the mental and physical health of people all around the world.

Covid-19 hampers on business companies, or simply, we can say it changed the industries' working style. Many small companies had to shut down their operations due to the economic crisis caused by this never-ending pandemic situation. Companies that are still trying to cope up with this "new normal" pandemic situation seem to have changed their employee hiring methods and techniques. Nowadays, they seem to be approaching more virtual interns and non-paid internship opportunities for students.

\subsection{Internships Are Rejected for the Covid-19 Issue}

An internship is an important part of a student's study life. They can explore themselves and get real-life work experience in the office or industry. Many universities provide internship opportunities for their students who are in their final year or the last semester of their university studies. But all universities don't provide internships in the last two semesters because they prefer students to finish all their courses first, then they can do an internship. The problem arose when a student had to wait after completing all the required credits for the internships, which are six months long.

\subsection{Comfortness to Work Outside}

The Covid-19 pandemic changed the lives of people dramatically. People who were not available in the house for an hour now have to sit all day long in the house. The funniest thing is that they are not even trying to go out during this pandemic. The reason is quite obvious, which is the fear of coronavirus. Everyone is trying to stay at home and do the work through the online method. Most offices shifted their services fully to the online system. Thus, workers do not need to go to the office, although they can do the office work sitting at home. Many internship students are doing internships online, yet they are facing many difficulties. Many of them work outside without any complaints, as some companies started the offline service but for a limited time and maintain the rules for preventing coronavirus.

With the onset of Covid-19, our regular life has become increasingly risky. 
Like other issues, going outside has become one of the most feared issues nowadays. Cause, The virus is transmitted through direct contact with coughing and sneezing from person to person [5]. Anyone can be infected by touching surfaces contaminated with the virus and touching any face part (eyes, nose, or mouth). For this transmission of Covid-19, most people are worried about going outside, even though Bangladesh is an overpopulated country, so there is always a high risk of rapidly sparing the Covid-19 virus.

According to our research, around $86 \%$ of people say that their family is concerned about their health when they go outside. They pointed out some reasons behind it.

Most family members are worried about their "elder" health status. From the recent coronavirus statistics, most of the affected people of coronavirus are over age. The family with grandparents or having more aged people does not want to go outside, even one of their family members does not want to go outside for the same reason.

Though there is no proper vaccine for this virus, most family members do not want other family members outside. A recent experiment by science says that "coronavirus can be transmitted via air", and this news affects a lot in itself.

In Bangladesh, most of the transportation system is public transportation. The buses contain almost 50 - 60 people at each tip. So, overall there is a high risk of spreading Covid-19 person to person.

Most families in Bangladesh have one earning member. It could be their father or brother or another member of the family. The main concern here is the income source. If the earning person is affected, then the whole family will face difficulties in their livelihood. It is both for the students also. In Bangladesh, most final year students have some other work besides their studies. Moreover, if they are affected by the virus, the whole family will suffer because most families are middle-class families.

If any person in the family is affected by the Covid-19, society does not take this usually nowadays. They made distance and stopped communication with that family. For this reason, the victim's family falls under mental pressure and has no other way to save it from ignorance and taboo at all.

\subsection{Provide Proper Equipment from Different Companies to Prevent Covid-19}

Most national, private, and multinational companies in Bangladesh did not offer an internship offer offline due to Covid-19 issues. Most of them also closed their offices for a specific time and waited for the regular days. However, health and safety are the primary concerns, so the maximum number of companies running their office/company via an online platform. They have said that though it was a little bit tough for them very early, they will become accustomed to it.

However, there is a question that arises: if the companies provide enough equipment to prevent corona, will the students go for the internship? In this question, we did a survey that showed that almost $86.6 \%$ of students agree with 
this if they maintain some safety criteria in their companies. For this reason, most of the university's fourth/final semester students are desperate to finish their undergraduate degrees as soon as possible. Moreover, without doing an internship/research, they will not finish the degree. So, they found a way to finish it.

Final year students told us some issues to solve. They point out some issues which will make the internship environment safer.

I have to ensure that the company has a proper health system. Each employee has to wash their hands with soap and water for at least 20 seconds [14]. If the soup is unavailable, they have to use hand sanitizer with at least $60 \%$ alcohol [14].

Each of the employees has to wear a facemask. That can be K-95 type or one-time use [15]. However, the mask's use is mandatory because all the office desks should be separated from each other. The distance will be at least 3 meters.

Though the public transportation system is a risky thing nowadays, if the company offers its own transportation system for employees, it would be more engaging for the employees.

Ensure ventilation systems operate correctly and provide acceptable indoor air quality for each space's current occupancy level [16]. Provide tissues and no-touch trashcans.

Discourage handshaking. However, this is a formality of every business but has to cope with the new normal, like encouraging employees to use other non-contact methods of greeting.

\subsection{Effect of Covid-19 on the Study}

Covid-19 19 hampers all sectors of our lives. The study is one that affects us the most. All the institutions are closed for around one year, and all the institutional work is hampered due to this. In particular, students like an intern stage where students need teachers most to guide them to what they should do or not [17]. But due to this, they have to do all these online. As we know, our way of life is not in other countries. Here, educational expenses are very high. Upon that, this coronavirus also hampers a student's way of continuing life. As a result, it affects the studies a lot. Students mainly gather soft skills like programming languages and hard skills like circuit design and robotics in labs when universities remain open. All the lab equipment which is expensive is available in laboratories. But in this pandemic situation, students can't access labs because most universities conduct online classes. Lab classes are also taken online, but students can't gain proper soft and hard skills through online labs, so it can hinder them in future higher studies or job hunting.

\section{Results and Analysis}

This section presents and discusses the research results. In this study, survey data was collected using a "Google Form". First, we set questions related to the 
topic and then finalized them. At that point, we began sharing this form by means of social media such as Facebook, LinkedIn, and numerous educational groups, as well as through the mail for more reach purposes among individuals. After that, we hold up a couple of days for a certain amount of response to work by the bulk of information. After we collected the data from the various university students, we started analyzing the response rate. We started analyzing papers regarding this topic on the internet to see whether the response from the students matches their preference. After that, we came up with a solution and started making a PI chart from the data we collected via the Google form from the students and started analyzing every question we set for. We set 25 questions on the Google form, and finally, we worked with 23 questions. In this survey study, a total of 300 students participated from different public and private universities from all around Bangladesh. The percentage of private university students was higher than the public universities in the respondent's list, as we can see in Figure 1. The majority of the respondents were from North South University. As we can see in Figure 2, the majority of the respondents were in the last $\left(12^{\text {th }}\right)$ semester or second last $\left(11^{\text {th }}\right)$ semester of their university studies. We also face some problems during research. We hope that most of the students filled up the survey forms to give accurate results after reading all the survey questions properly. We have to assume it was because it was an online survey, so we could not attend physically when students filled up survey forms. We found very few research papers on this topic because it is a new area of research. So, we can't review a lot of research papers for this reason.

In Figure 3, we see that almost $54.2 \%$ of students answered that internships are vital for learning and developing skills. Though it is a corona time, they do not believe that it is more valuable than any other option. Around 39.8\% of students answered they strongly agree with this. Moreover, the rest of the students disagree with that.

Participants Number with University Name

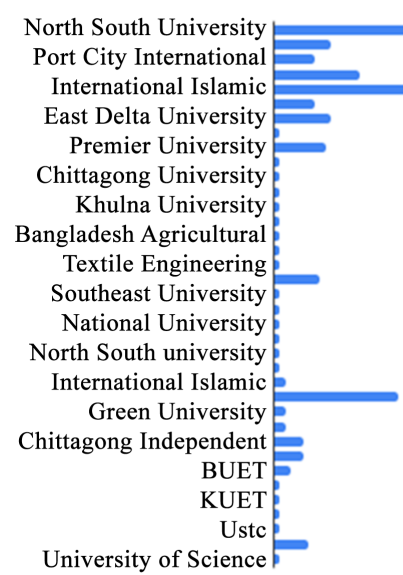

50

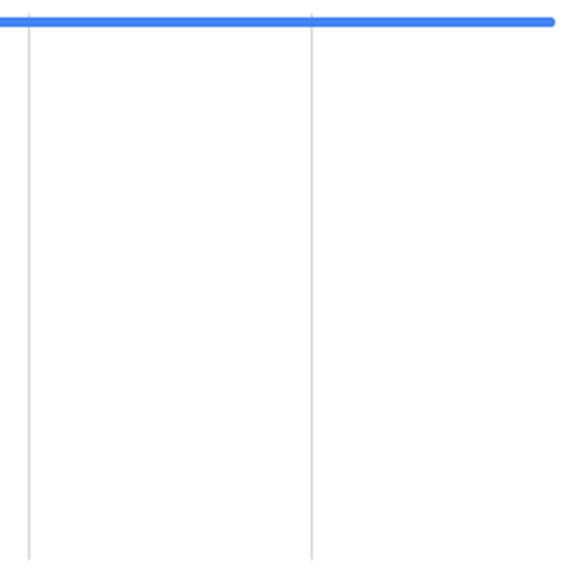

100
150

Figure 1. Number of participants from different universities. 


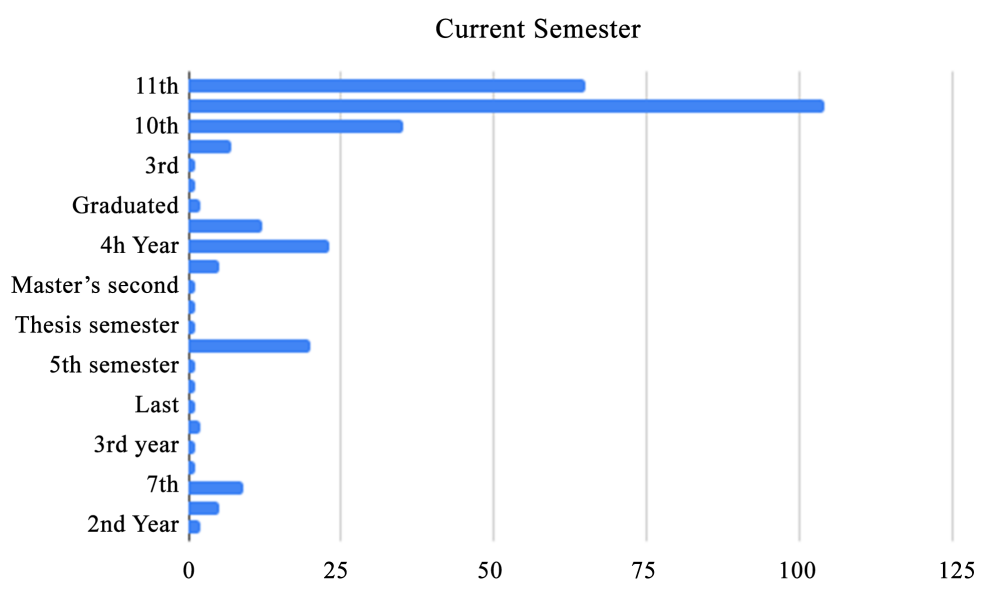

Figure 2. Students' current semester number.

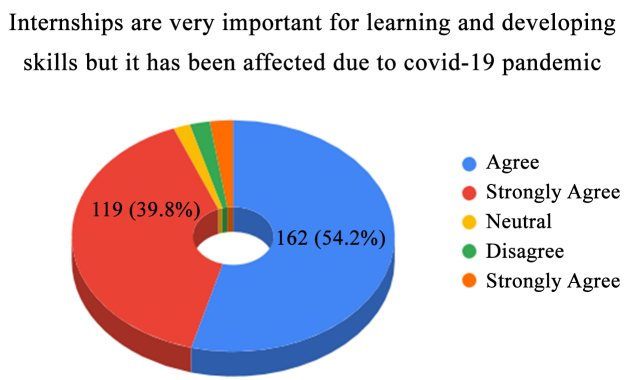

Figure 3. Effect of internship ratio due to Covid-19.

Though it is a tough time for almost all students, most students say that internships are essential and play a vital role in their education, learning, and development sectors. Most of them do not even think about the second option without it. So, we can easily say that most students want to do an internship in their final year, but they are unable to because of the pandemic.

In Figure 4, the result shows that $35.1 \%$ have said that their university encourages them to take internships during the Covid-19 pandemic. $31.1 \%$ of students said the university they are studying at did not encourage them to take an internship program during this pandemic. $33.8 \%$ of students have no idea about this.

Most universities agree with internships; most of them prefer offline internships. Because, though the $100 \%$ accurate vaccine has not been invented yet, there is always a safety issue. Some universities also encourage students to go for an internship program if there is proper safety equipment for the employees and they maintain the proper guidelines. Moreover, the rest of the university does not encourage their students to do an internship but encourages them to do research work.

In Figure 5, we came to find that over 300 internship students took part and viewed their thoughts as over $62.2 \%$ of students said that universities should make an option to do research instead of an internship for graduation and $28.4 \%$ said that universities could help students to find an internship. 
Does your university encourage you not to take internship during covid-19 pandemic?

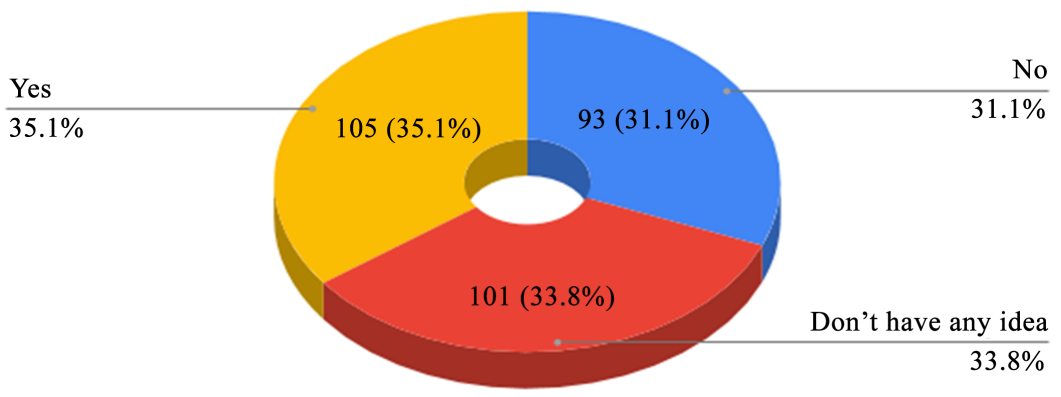

Figure 4. Universities encourage ratio not to take the internship for Covid-19.

Instead of internship what the university can do for graduation. What do you think?

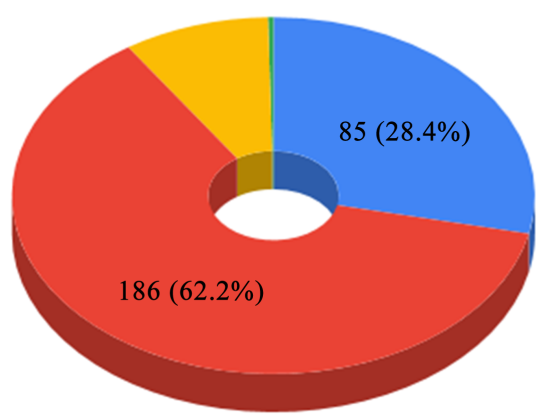

University can help every student to find internship

- Make option to do research

University can graduate all students without internship

I think they can make option to do research and also can help every student to find Internship as well.

Figure 5. Ratio of alternatives for internship.

Therefore, it could easily be said that research is a good option during this pandemic for complete graduation.

In Figure 6, we can see that there is a close contest between yes or no. Therefore, it clearly shows what this internship means to them. Due to the uncontrollable spread of corona virus most of the companies called off the internship offer at this recent time; thus, many of the students who are in their last semester of their university life are left with just the internship which is mandatory for most of the institutions or undergrad program. In that case, most of our participants said they applied for the internship during this pandemic and half of the participants said they did not bother to apply.

In Figure 7, from these statistics, there are over 300 and more students. Here, around $44.5 \%$ of the students did not even apply for their internship to any company, and around $40 \%$ of them were rejected. It clearly shows how this pandemic affects intern students.

In Figure 8, around $82 \%$ of students think that an internship is best for their professional life. I also think that. When one goes to that place, gains and experiences the environment of that office, it will boost them and give them a visual idea of what they are going to face in their upcoming future. 
Did you apply for internship during this pandemic?

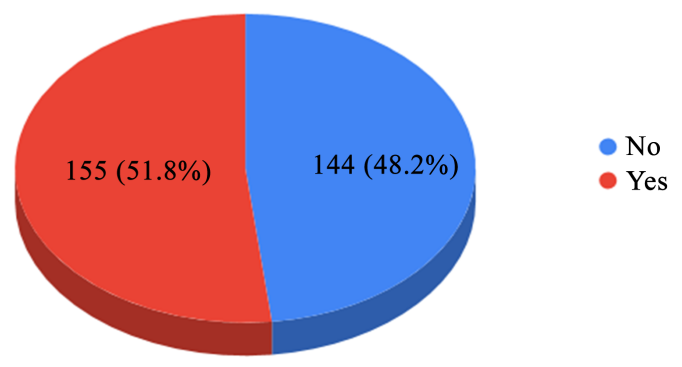

Figure 6. Number of students applied for the internship.

Are you rejected by any company for covid-19 issue?

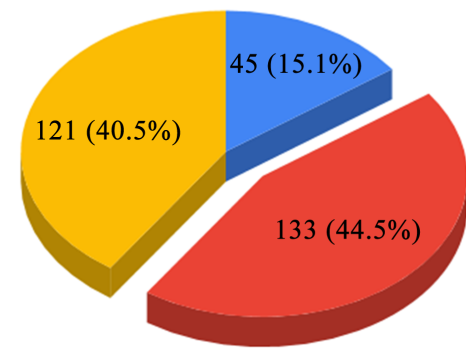

No

- Didn't applied for internship

-Yes

Figure 7. Number of rejected students for internship.

Which is more useful for the professional working life? What do you think?

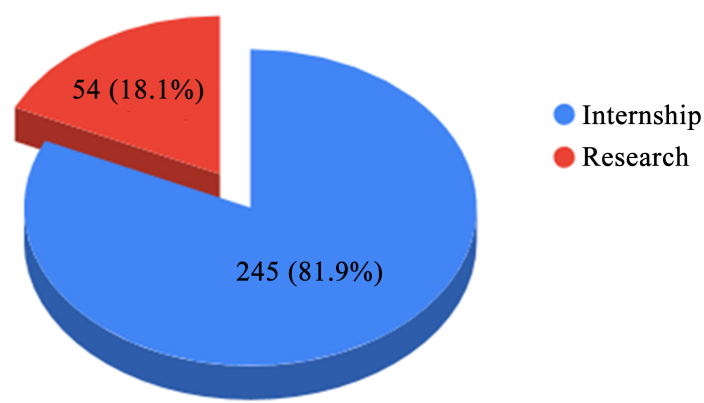

Figure 8. Preference for professional working life.

Figure 9 clearly shows that even companies are more concerned about the health of both their employees and students. In addition, around $18 \%$ of students face problems like they find out most companies don't even offer internships during this time. It clearly shows how this pandemic affects intern students.

In Figure 10, here, 50.8\% of students answered that their university did not help them to get an internship. $29.8 \%$ of students answered that their universities emailed them to inform them about different companies which offered internships. $19.4 \%$ of students answered that their universities directly contact different companies to get internships for every student. 
What are the reasons do you think that different company shown to reject internship during pandemic?

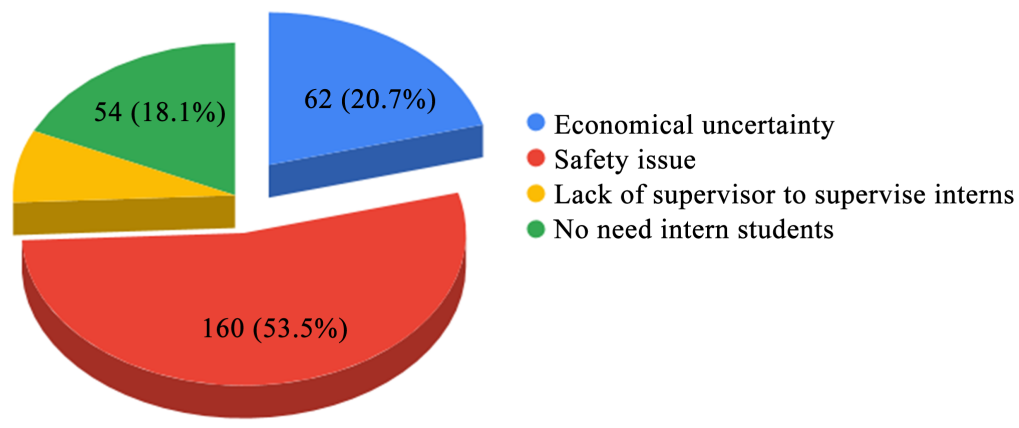

Figure 9. Reasons behind the rejection of internship.

How does your university help to get Internship?

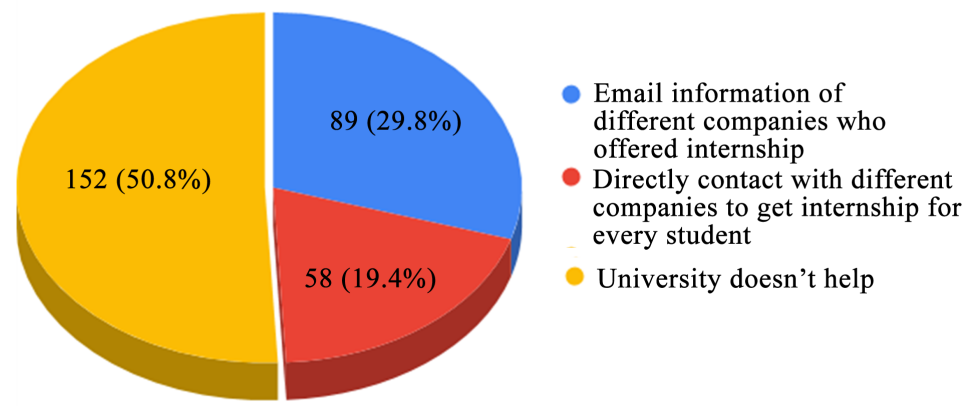

Figure 10. Universities help to get the internship.

Therefore, here we can see that most universities do not help their students to get internships. Some private universities helped their students to inform them about different companies that offered internships, and a few universities directly helped their students to get internships, which was appreciated.

In Figure 11 from these survey questions, $43.5 \%$ of students said that they found remote internship companies where they could work for the company by staying home. $36.5 \%$ of students said that they did not have any idea about the remote internship, and $20.1 \%$ of students said that they did not find a remote internship.

Therefore, we can say that remote internships are now a popular thing, and most students have ideas about remote internships because surveys say that $43.5 \%$ of students found companies that offer remote internships, which is a new thing, but it is getting popular, and it is helpful for internship students during this pandemic.

In Figure 12 of this survey, $57.2 \%$ of students said that they preferred remote internships during this pandemic, and $42.8 \%$ of students said that they did not prefer remote internships.

This is a close-call survey where the yes: no ratio is $57.2 \%: 42.8 \%$ where the majority of students preferred remote internships because maybe remote 
Did you find any company which offers remote internship where you can work for the company by staying home?

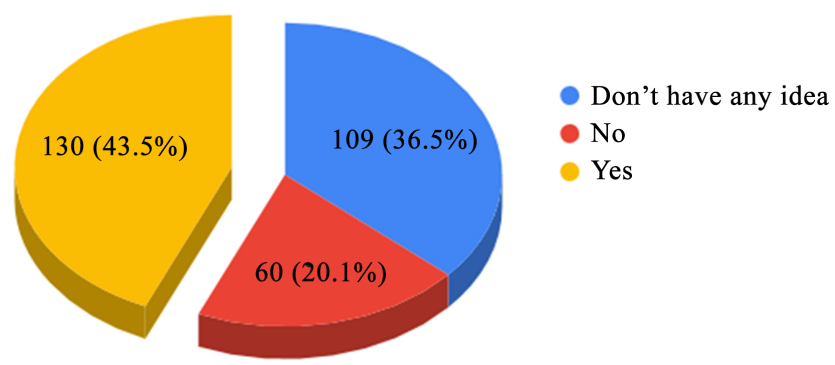

Figure 11. Finding the remote internship.

Do you prefer remote internship during pandemic situation?

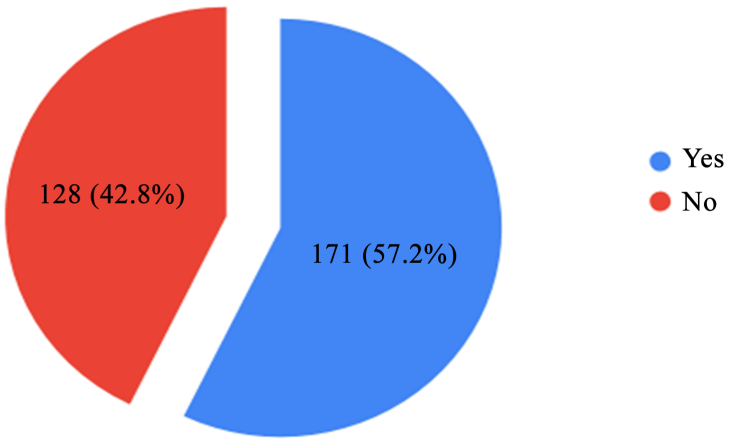

Figure 12. Preference of remote internship.

internships helped them to graduate from university and they didn't have to wait for graduation. On the other hand, $42.8 \%$ of students did not want a remote internship because they thought they could not get the real experience of office life.

In Figure 13, 44.8\% of students said that they could face all of the problems that they can't get real experience of working in an office, can't know how to survive in corporate life, can't face the real scenario of problem-solving, and can't get the experience of working in a team. $28.8 \%$ of students answered that they could not get real experience of working in an office. $12.3 \%$ of students said that they could not face the real scenario of problem-solving. $8.1 \%$ of students said that they could not get the experience to work in a team; $6 \%$ of students said that they could not know how to survive in corporate life.

So, most of the students (44.8\%) agreed that they could face all of the problems in a remote internship, which they did not face in the real internship. The remote internship is a solution to this pandemic, but it is not a full solution because of some limitations.

In Figure 14 from this survey, $49.2 \%$ of students answered that they were comfortable working with a virtual team. $27.1 \%$ of students answered that they were not comfortable working with a virtual team, and $23.7 \%$ of students answered that they did not have an idea about the virtual tram. 
What are the problems can you face for remote internship?

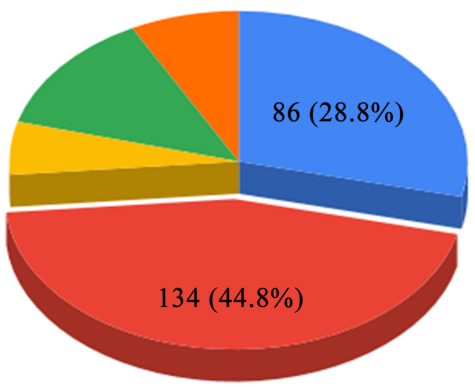

- Can't get real experience of work in office

- All of the above

- Can't know how to survive in corporate life

- Can't face the real scenario of problem solving

Can't get the experience to work in a team

Figure 13. Problems in the remote internship.

Are you comfortable working with virtual teams during the internship?

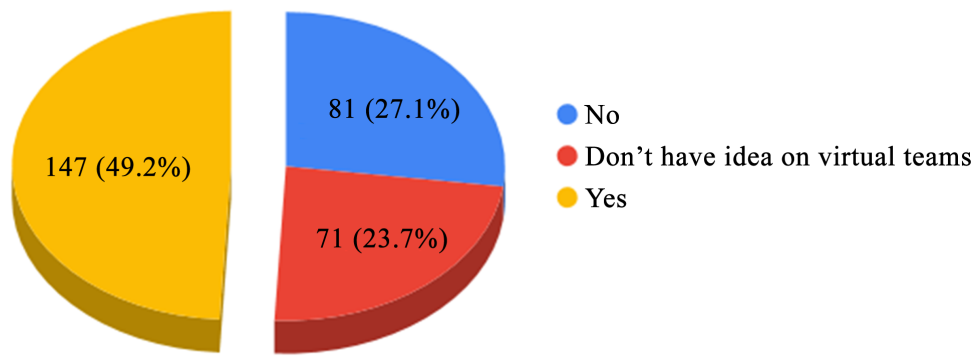

Figure 14. Working with a virtual team.

So, we can see that most of the students (49.2\%) agreed to work with a virtual team, which is good for them to complete an internship during this pandemic, and they are also able to adapt to new things, which is also good for them. 27.1\% of students also said that they are not comfortable working in a virtual team. Maybe they want to get the real feeling of working as a team member.

In Figure 15, we can see that $86.3 \%$ of students think that internships are more useful for professional working life than research. It is obvious that the majority of students think that. Because whenever any student applies for a job, the very first thing that is asked is, do we have any experience? This is sometimes very hard to answer because of the lack of experience of working through internships. If the students got the internship, they could experience the way of working in the industry of the company. However, due to this pandemic situation, most students do not get the chance to do internships in any company or do not get that taste of working and discovering real-life industry-level work experience.

In Figure 16, we can see that among 300 responses, 121, which are $40.5 \%$ of the whole responses, think that their biggest concern is not getting enough internship opportunities. Because the internship opportunities drastically dropped due to the pandemic, that affected the final year students badly and raised their concerns. There is mixed concern among the rest of the students, which is $27.8 \%$ 
Is the internship more useful for the professional working life than research?

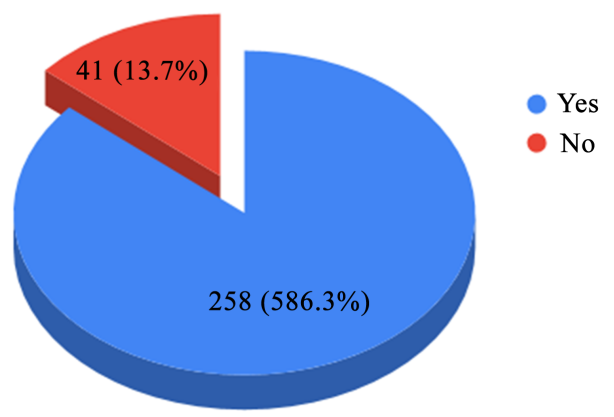

Figure 15. Impact of internship on professional working life.

What is the biggest concern for your career at this time?

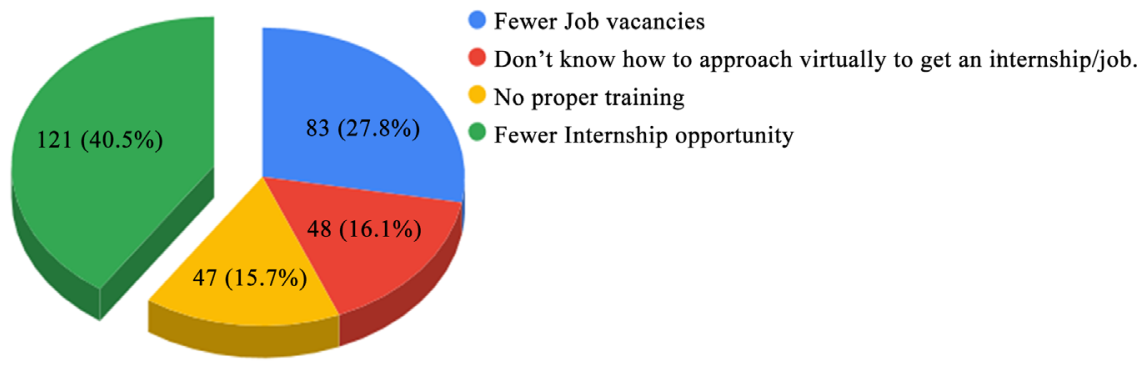

Figure 16. Concern of career for Covid-19.

of students think their biggest concern is that there are very few job vacancies nowadays because of the Covid-19 effect. $15.7 \%$ of them think not getting proper training is their biggest concern, and the rest $16.1 \%$ of students said they do not know how to approach getting an internship as a bigger concern at this time. Because students are not familiar with this new normal, which is working virtually, they face many technical as well as physical challenges in attending and approaching virtual internships.

In Figure 17, you can see that, $91.3 \%$ of the respondents think that companies nowadays hire fewer employees than in previous years. It is obvious because of the current Covid-19 pandemic situation; companies are not recruiting new people because of the economic crisis. It is a huge problem for new graduate and internship students.

Because they do not find the scope or opportunities to explore themselves by working at an industry level.

In Figure 18, we can see that 227 students, which are around $75.9 \%$ of them, said their university allows them to do internships in the last two semesters, which is good because it saves the extra six months times from the students' account. We also know that maximum companies take interns for at least 4 months, which is good for achieving high knowledge of practical work and relating this to the education gained at university stage. Thus, in the last two 


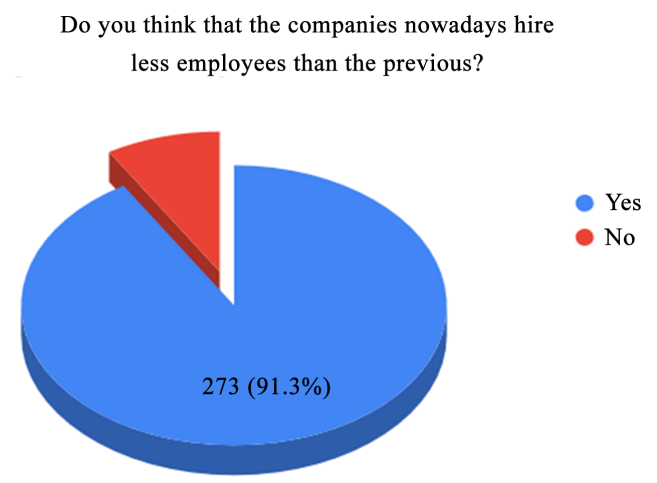

Figure 17. Companies hire fewer employees.

Does your university allow the internship in the last two semester?

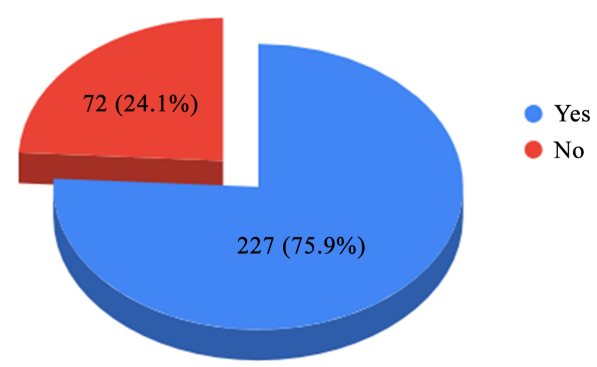

Figure 18. Internship in the last two semesters.

semesters, students get enough time to receive practical knowledge through internships. This also saves an extra 4 months from a student's life after completing last semester, which is somewhat beneficial.

In Figure 19, the most surprising thing happened when we looked at that $65.9 \%$ of students said they are comfortable working outside of the home during this pandemic. This result is obvious because of the difficulties they are facing online due to a lack of experience. They are not getting the real office experience and help, which they should have got offline. $34.1 \%$ of them said they are not comfortable working outside during this pandemic. It is because of the fear of the coronavirus. They are more health-conscious and comfortable with the online system of work.

In Figure 20 here, $86 \%$ of students have said that their family is concerned about going outside at this time. Moreover, the rest of the students said that (14\%) does not seem concerned about going outside.

The family concerned about health has said that health status, lack of vaccines, transportation system, one earning member, and social fear are the main reasons for their concern. Though Bangladesh is an overpopulated country, there is always a high risk of rapidly sparing the Covid-19 virus.

In Figure 21, 86.6\% of the students said that if the companies provide enough equipment to prevent corona, they will go for the company's internship program. Moreover, the rest of the percentage of students does not agree with that. 
Are you comfortable enough to work outside of the house during a pandemic?

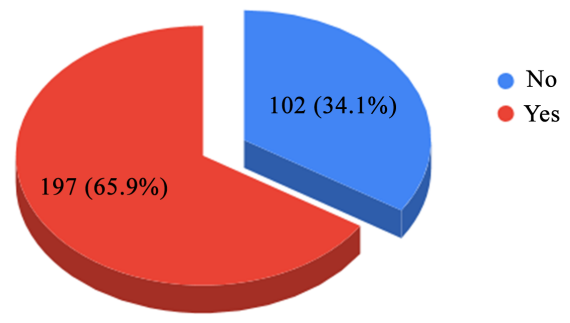

Figure 19. Working outside during the pandemic time.

Is your family concerned about going outside at this time

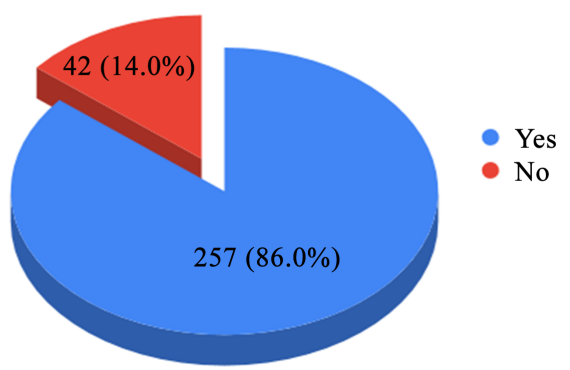

Figure 20. The concern of family for working outside.

If companies provide enough equipment to prevent corona, do you still think to go for an internship at the pandemic?

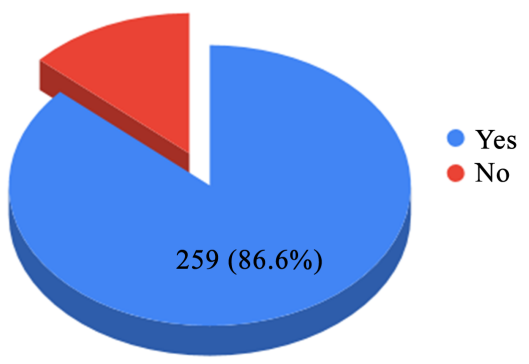

Figure 21. Provide enough equipment to prevent Covid-19.

If we talk about the facts behind it, then most of the students have said that if the companies fully maintain the guidelines that WHO and the government have decided and maintain the companies' proper safety kit, they are ready to go for the internship program without any hassle.

In Figure 22, around 92\% of them think the same that it would be quite hard for them to have a good job during this pandemic situation. To overcome this situation, I think the government should take steps to create more job space for new people.

In Figure 23, around 93\% of students say that they face problems while studying during this pandemic situation. Those who have voted no might have any problems like others. 
Do you think it will be difficult for you to get a job for Covid-19 situation?

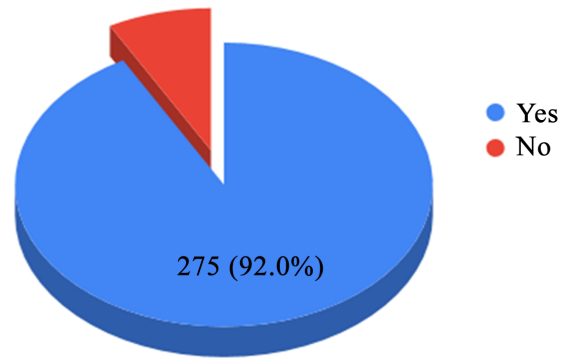

Figure 22. Getting a job during the pandemic situation.

Does covid-19 hamper your study?

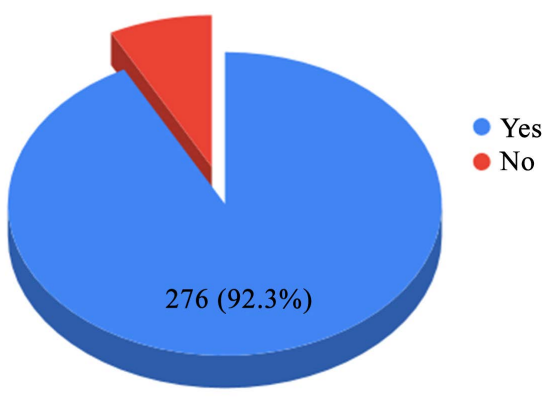

Figure 23. Hamper of study for Covid-19 issue.

\section{Overall Analysis of Survey Results}

At the beginning of the Covid-19 pandemic final year, students suffered more from the lack of internship opportunities, and their graduation remained delayed. But after a while, some alternatives came out, like remote internships, where a student could work for his/her intern institution from home, and another alternative, which helped the final year students most, was research. Most universities encouraged their students to do research instead of internships, which helps students to complete their graduation, but some problems were created. All of the students didn't want to do research. They thought that an internship was more useful than research for professional working life. Many students wanted to do internships because, in South Asia, getting a respectful job is important for students for many reasons. So, a lot of students want to do an internship, which helps them to get a real feeling of a job. Students get the experience of corporate life; they can know how to work in a team, how to solve problems in the job sector, and last of all, they want a certificate. But most companies stopped offering internships during this pandemic because of safety issues. Some companies offer remote internships where anyone can work from home, but students say that they could not find the real feeling of an internship in a remote internship. Many companies rejected the internship proposal because of the Covid-19 issue. 
Most universities helped their final year students during the Covid-19 situation. The university authorities emailed information about different companies that offered internships. Universities did not pressure their students not to take an internship but encouraged them to do alternative things than an internship.

The next concern for final year students is finding a job. Most students think that it will be difficult for them to get a desired job in the Covid-19 situation because a lot of institutions have already reduced their offer of new employees and also cut off some percentage of salaries for the Covid-19 situation.

\section{Conclusions}

The education sector was hampered more because of the Covid-19 pandemic, but slowly all educational institutions broke down most of the obstacles. Most educational institutions started conducting classes, exams, assignments, vivas, and projects through an online platform, which was a new idea for all of us, but after some time, students and teachers could adopt online teaching and learn in a short time.

Final year students suffer most because, in the final year, every student must do projects, internships, and research where a student learns these things under the direct guidance of a teacher. These obstacles would also be overcome online where the remote internship was introduced; students did research projects online where students could show their project progress and teachers could be able to correct the mistakes of the students and also be guided to see the project.

\section{Acknowledgements}

Authors of this paper would like to thank the ECE Department of North-South University.

\section{Conflicts of Interest}

The authors declare no conflicts of interest regarding the publication of this paper.

\section{References}

[1] Bugis, B.M. (2020) The Impact of the Covid-19 Pandemic on Internship Activities at Health Organizations in Saudi Arabia. Hospital Topics, 99, 22-28.

[2] SIRVA Worldwide Relocation \& Moving (2020) Impacts of COVID-19 on 2020 Internship Programs Global Best Practices and Benchmarking. https://www.sirva.com/docs/default-source/resources-docs/white-papers-guides/20 20/sirva_impacts-of-Covid-19-on-intership-programs.pdf?sfvrsn=2ee6ef33_15

[3] The University of Kansas Medical Center (2020) Predoctoral Internship in Clinical Psychology.

https://www.kumc.edu/school-of-medicine/psychiatry-and-behavioral-sciences/clin ic-

al-psychology-training-programs/predoctoral-internship-program/impact-of-Covid -19-pandemic-on-training.html

[4] Maio, J. (2018) 10 Reasons Why an Internship is Important to All Students. 
https://blog.suny.edu/2018/06/10-reasons-why-an-internship-is-important-to-all-st udents/

[5] UNICEF (2019) Coronavirus Disease (Covid-19): What Parents Should Know. https://www.unicef.org/pacificislands/stories/coronavirus-disease-Covid-19-what-p arents-should-know

[6] Khan, M.M., Tahsinur Rahman S.M. and Islam, S.T.A. (2021) Online Education System in Bangladesh during Covid-19 Pandemic. Creative Education (CE), 12, 441-452. https://doi.org/10.4236/ce.2021.122031

[7] Khan, M., Rahman, S. and AnjumIslam, S. (2021) The Use of Telemedicine in Bangladesh during Covid-19 Pandemic. E-Health Telecommunication Systems and Networks, 10, 1-19. https://doi.org/10.4236/etsn.2021.101001

[8] Seladorai, D. and Mohamed, M. (2021) Digital Learning among Postgraduate Students in the Times of Covid-19: A Literature Review. Creative Education, 12, 1494-1502. https://doi.org/10.4236/ce.2021.127114

[9] Tamim, H., Sultana, F., Tasneem, N., Marzan, Y. and Khan, M.M. (2021) Class Insight: A Student Monitoring System with Real-time Updates Using Face Detection and Eye Tracking. 2021 IEEE World AI IoT Congress (AIIoT), Seattle, WA, USA, 10-13 May 2021, 213-220. https://doi.org/10.1109/AIIoT52608.2021.9454176

[10] Ghani, T., Jahan, N., Khan, M.M., Tahsinur Rahman, S.M. and Islam, S.T.A. (2021) Development and Analysis of a Machine Learning Based Software for Assisting Online Classes during Covid-19. Journal of Software Engineering and Applications, 14, 83-94. https://doi.org/10.4236/jsea.2021.143006

[11] Thandevaraj, E., Gani, N. and Nasir, M. (2021) A Review of Psychological Impact on Students Online Learning during Covid-19 in Malaysia. Creative Education, 12, 1296-1306.

[12] Stawicki, S.P., et al. (2020) The 2019-2020 Novel Coronavirus (Severe Acute Respiratory syndrome Coronavirus 2) Pandemic: A joint American College of Academic International Medicine-World Academic Council of Emergency Medicine Multidisciplinary Covid-19 Working Group Consensus Paper. Journal of Global Infectious Diseases, 12, 47-93.

[13] Islam, S. et al. (2020) Covid-19-Related Infodemic and Its Impact on Public Health: A Global Social Media Analysis. American Journal of Tropical Medicine and $\mathrm{Hy}$ giene, 103, 1621-1629.

[14] Hadaway, A. (2020) Handwashing: Clean Hands Save Lives. Journal of Consumer Health on the Internet, 24, 43-49.

[15] WHO (2020) Mask Use in the Context of Covid-19.

https://www.who.int/publications/i/item/advice-on-the-use-of-masks-in-the-comm uni-

ty-during-home-care-and-in-healthcare-settings-in-the-context-of-the-novel-coron avirus-(2019-ncov)-outbreak

[16] CDC (2019) Guidance for Businesses \& Employers: Plan, Prepare and Respond to Coronavirus Disease.

https://www.cdc.gov/coronavirus/2019-ncov/community/guidance-business-respon se.html

[17] Dani, R., Kukreti, R., Negi, A. and Kholiya, D. (2020) Impact of Covid-19 on Education and Internships of Hospitality Students. International journal of Current Research and Review, 12, 86-90. 